\begin{tabular}{ccc}
\hline International Journal of Current Research in \\
Biosciences and Plant Biology \\
Volume $4 \cdot$ Number 2 (February-2017) ・ ISSN: 2349-8080 (Online) \\
PUBLISHERS
\end{tabular}

\title{
Sensitivity of Azotobacter chroococcum to Exogenous Nitrogen in Rice Cultivation in Terms of Nitrate Reductase Activity in Leaves and Nitrogenase Activity on the Root Surface of the Inoculated Rice Cultivar and Its Effect on Microorganism Population in Rhizosphere Soil
}

\author{
Mihirlal Roy ${ }^{1}$, Sibani Saha ${ }^{2}$ and Jhuma Das ${ }^{3}$ \\ ${ }^{I}$ Tripura State Council for Science \& Technology, A.R.Complex, Agartala-799 006, Tripura India \\ ${ }^{2}$ Department of Fisheries, Government of Tripura, College Tilla, Agartala799 004, Tripura, India \\ ${ }^{3}$ IDSP, State Health and Family Welfare Society, Agartala799 006, Tripura, India
}

*Corresponding author.

\begin{tabular}{|c|c|}
\hline Abstract & Article Info \\
\hline \multirow{8}{*}{$\begin{array}{l}\text { The experiment on inoculation of Azotobacter chroococcum on cv. IR- } 64 \text { of Oryza sativa } \\
\mathrm{L} \text {. in integration with different levels of exogenous nitrogen (urea-nitrogen) conducted on } \\
\text { paddy soil in earthenware pots in rainy autumn season in West Tripura. The result } \\
\text { indicated that, integration of } 50 \text { and } 75 \% \text { of the recommended dose of exogenous nitrogen } \\
\left.\text { fertiliser (i.e., } 40 \mathrm{~kg} \mathrm{Nha}^{-1} \text { and } 60 \mathrm{~kg} \mathrm{~N} \mathrm{ha}^{-1}\right) \text { is the optimum level when the rhizobacteria, } \\
\text { A. chroococcum results better in vivo nitrate reductase activity in the leaves, in vivo } \\
\text { nitrogenase }\left(\mathrm{N}_{2} \text {-ase) activity on the root surface and viable counts, i.e., colony forming }\right. \\
\text { units (CFU) of microorganisms of rhizosphere soil of inoculated plants. Further increase } \\
\text { of exogenous nitrogen inhibited both the nitrate reductase and nitrogenase activity and } \\
\text { also decreased the population of microorganisms from rhizosphere soil. }\end{array}$} & Accepted: 15 January 2017 \\
\hline & Available Online: 06 February 2017 \\
\hline & Keywords \\
\hline & Azotobacter chroococcum \\
\hline & Colony forming units (CFU) \\
\hline & Exogenous nitrogen \\
\hline & Nitrate reductase activity \\
\hline & Nitrogenase activity \\
\hline
\end{tabular}

\section{Introduction}

Nitrogen is an essential plant nutrient, but most of the soils are deficient of $\mathrm{N}$. On the other hand modern varieties of cereal crops are N-responsive. Hence, input of exogenous nitrogen in agricultural fields is essential for good yields. In this context, urea is the most convenient $\mathrm{N}$ source. But unfortunately less than $50 \%$ of the applied urea is only used by plant (Garbet et al., 1998; Halvarson et al., 2002). There are also reports of efficiency of N-fertilizer only to the extend $30-40 \%$ or even lesser (De Datta, 1978; Chowdhury and Khanif, 2001 and 2004). Excessive fertilizer does not give better productivity (Kalininskaja, 1988), though affects the physico-chemical properties of the soil causing environmental pollution (Chowdhury and Kennedy, 2005). In addition, the manufacturing process of $\mathrm{N}$ fertilizers including urea relies on non-renewable fossil fuels (the production of $1 \mathrm{~kg} \mathrm{~N}$ fertilizer requires 38, 000 $\mathrm{KJ}$ of fossil energy), resulting significant emissions of green house gases (Refsgaard et al., 1998; Anonymous, 2006). Due to increase of the cost of fossil fuels day by day, cost of $\mathrm{N}$-fertilizers are also increasing correspondingly and becoming economic constrains for the farmers (Begum et al., 2011). Therefore, in recent years, in consideration to both economics and 
environment, scientists are advocating for biological nitrogen fixation (BNF) to substitute commercial available $\mathrm{N}$-fertiliser in rice cultivation.

Different BNF system has different potentials to provide $\mathrm{N}$ supplement. Among them, one is Plant Growth Promoting Rhizobacteria (PGPR), a group of bacteria that actively colonize plant roots and increase plant growth and yield (Wu et al., 2005). But, in case of PGPR too, there are reports of inhibitory effects of Nfertilization (Roger and Kulasooriya, 1980). Reviewing the associative nitrogen fixation in low land rice, Shrestha and Maskey (2005) postulated that, while in vitro experiments, long ago showed that $\mathrm{N}$-fixation is retarded when mineral $-\mathrm{N}$ is present, there has been little study whether it would affect $\mathrm{N}_{2}$-fixation in the soil when the plants are present. In this context, the aim of the present study was to verify the sensitivity of one PGPR, viz., A. chroococcum to exogenous supply of N in the form of urea in the soil when the rice plants are present.

Inoculation effect on cultivation of plants in agricultural sciences is mostly monitored in terms of changes in the mass of entire plants or their selected organs after harvest. There is scanty information on the effect of the exogenous nitrogen on cereal plants in terms of biochemical parameters, which are indicator of physiological plant conditions (Falkowski et al., 1990; Swedrzynska, 2000). Hence, in present study inoculation effect of $A$. chroococcum in combination with exogenous supply of urea-N was studied in terms of two enzymatic activities, viz., in vivo nitrate reductase (NR) activity of leaves and in vivo nitrogenase $\left(\mathrm{N}_{2}\right.$-ase $)$ activity on root surface during vegetative period of the rice plant apart from study in terms of Colony Forming Units (CFU) of microorganisms in rhizosphere soil.

\section{Materials and methods}

The experiment on inoculation of A. chroococcum in integration with different levels of exogenous nitrogen in the form of urea $\left(\mathrm{NH}_{2}-\mathrm{CO}-\mathrm{NH}_{2}\right)$ on cv. IR -64 of Oryza sativa $\mathrm{L}$. was conducted in rainy autumn season in earthenware pots. The paddy soil (unsterilized; sandy loam; pH-6.0; available nitrogen $0.612 \%$; available phosphorus $0.838 \%$; available potassium $0.678 \%$ ) from farmers field in West Tripura District was collected and mixed to homogenecity and filled in earthenware pots (22 cm diameter, $22 \mathrm{~cm}$ height, capacity to hold $8 \mathrm{~kg}$ sandy-loam soil) on which plants were transplanted on $21^{\text {st }}$ day from similar earthenware nursery pots having similar soil, in which water soaked seeds (for $72 \mathrm{hrs)} \mathrm{of}$ rice was sown.

In integration of inoculation of $A$. chroococcum on rice cultivar, three levels of exogenous nitrogen (40,60 and $80 \mathrm{~kg} \mathrm{ha}^{-1}$ ) in the form of urea and a control (without nitrogen) was applied as basal dose in three splits (50\% at 10 days after transplantation, $25 \%$ at 30 days after transplantation and balance $25 \%$ at 50 days after transplantation) in the soil. Both the phosphorous [single super phosphate $\left(\mathrm{P}_{2} \mathrm{O}_{5}\right.$ in the form of $\left.\mathrm{Ca}\left(\mathrm{H}_{2} \mathrm{PO}_{4}\right) \cdot 2 \mathrm{H}_{2} \mathrm{O}\right]$ and muriate of potash $(\mathrm{KCl})$ respectively were also applied @ $40 \mathrm{~kg} \mathrm{ha}^{-1}$ during final soil preparation (one day before transplanting rice seedlings).

The A. chroococcum was procured from the Institute of Microbial Technology (IMTECH), Chandigarh and maintained in specific culture broth under standard aseptic condition. The stock of the said bioinoculant was made ready by thoroughly mixing $100 \mathrm{ml}$ culture at its maximum growth (96 hrs). For basal application for inoculation of rice cultivar, $100 \mathrm{ml}$ culture was again mixed with $1 \mathrm{~kg}$ pre-sterilized $\left(100^{\circ} \mathrm{C}\right)$ rice husk powder thoroughly. The said rice husk was sterilized in a hot air oven at $100^{\circ} \mathrm{C}$ for $6 \mathrm{hrs}$.

The treatment combinations were $\mathrm{N}_{0} \mathrm{~B}_{0}=$ no $\mathrm{N}+$ no bioinoculant, $\mathrm{N}_{1} \mathrm{~B}_{0}=40 \mathrm{~kg} \mathrm{~N} \mathrm{ha}^{-1}+$ no bioinoculant, $\mathrm{N}_{2} \mathrm{~B}_{0}=60 \mathrm{~kg} \mathrm{~N}^{-1}+$ no bioinoculant, $\mathrm{N}_{3} \mathrm{~B}_{0}=80 \mathrm{~kg} \mathrm{~N}$ $\mathrm{ha}^{-1}+$ no bioinoculant, $\mathrm{N}_{0} \mathrm{~B}_{1}=$ no $\mathrm{N}+$ A. chroococcum, $\mathrm{N}_{1} \mathrm{~B}_{1}=40 \mathrm{Kg} \mathrm{N}^{-1}+$ A. chroococcum, $\mathrm{N}_{2} \mathrm{~B}_{1}=60 \mathrm{~kg} \mathrm{~N}$ $\mathrm{ha}^{-1}+$ A. chroococcum, $\mathrm{N}_{3} \mathrm{~B}_{1}=80 \mathrm{~kg} \mathrm{~N} \mathrm{ha}^{-1}+$ A. chroococcum.

In fresh leaves of plant cultivar, the in vivo nitrate reductase (NR) activity was measured by the method of Hageman and Hucklesby (1971). The in vivo nitrogenase $\left(\mathrm{N}_{2}\right.$-ase) activity on the freshly harvested detached root surface of the cultivar was determined by following the method of Srivastava et al. (1980), which is modified Conway's microdiffusion method (Conway, 1957). The numbers of viable counts rather colony forming units (CFU) of microorganisms present in rhizosphere soil were determined by serial dilution technique by standard plate counting method (Vincent, 1970).

For in vivo nitrate reductase (NR) activity in leaves, 3 replicates we taken. For both the measurement of in vivo nitrogenase $\left(\mathrm{N}_{2}\right.$-ase $)$ activity on root surface and 
determination of colony forming units (CFU) in rhizosphere soils, 5 replicates were taken. The data were processed suitably to find out standard error of the mean and Critical Difference (CD) at 5\% P.

\section{Results}

Both the inoculation of $A$. chroococcum and input of exogenous nitrogen at different levels alone or in combination resulted increase in in vivo NR activity in the leaves of rice cultivar (Table 1). On input of exogenous nitrogen alone at the level of $40 \mathrm{~kg} \mathrm{ha}^{-1}\left(\mathrm{~N}_{1} \mathrm{~B}_{0}\right)$, the in vivo NR activity was recorded highest but increase of nitrogen to $60 \mathrm{Kg} \mathrm{ha}^{-1}$ resulted decrease in NR activity $\left(\mathrm{N}_{2} \mathrm{~B}_{0}\right)$. Further increase, i.e., input of $80 \mathrm{~kg} \mathrm{ha}^{-1}$, only resulted insignificant increase in the nitrate reductase activity $\left(\mathrm{N}_{3} \mathrm{~B}_{0}\right)$ and this increase was even less than the treatment having inoculation of $A$. chroococcum alone $\left(\mathrm{N}_{0} \mathrm{~B}_{1}\right)$.

Table 1. Effect of exogenous nitrogen at different levels alone or in combination with inoculation of A. chroococcum on Oryza sativa L. (cv. IR - 64) in terms of in vivo nitrate reductase in leaves, nitrogenase on root surface and number of colony forming units of micro-organisms in rhizosphere soil. The plants were raised in paddy fields.

\begin{tabular}{|c|c|c|c|}
\hline Treatments & $\begin{array}{l}\text { In vivo nitrate reductase (NR) } \\
\text { activity }\left(\mu \mathrm{mol} \mathrm{NO}_{2}-\mathrm{h}_{-\mathrm{g}^{-1}}\right)\end{array}$ & $\begin{array}{l}\mathrm{N}_{2} \text {-ase produced from root } \\
\text { surfaced microorganism } \\
\left(\mu \mathrm{mol} \mathrm{NH}_{3} \mathrm{~h}-\mathrm{g}^{-1}\right)\end{array}$ & $\begin{array}{l}\text { Colony forming units of } \\
\text { microorganisms (Log of actual } \\
\text { numbers) }\end{array}$ \\
\hline $\mathrm{N}_{0} \mathrm{~B}_{0}$ & $2.86 \pm 0.31$ & $59.40 \pm 4.62$ & $17.75 \pm 0.147$ \\
\hline $\mathrm{N}_{2} \mathrm{~B}_{0}$ & $6.52 \pm 0.24$ & $59.41 \pm 3.05$ & $18.417 \pm 0.923$ \\
\hline $\mathrm{N}_{3} \mathrm{~B}_{0}$ & $6.68 \pm 0.38$ & $59.32 \pm 3.91$ & $17.394 \pm 0.993$ \\
\hline $\mathrm{N}_{2} \mathrm{~B}_{1}$ & $6.36 \pm 1.03$ & $91.36 \pm 6.69$ & $18.278 \pm 0.733$ \\
\hline $\mathrm{N}_{3} \mathrm{~B}_{1}$ & $3.24 \pm 0.63$ & $50.68 \pm 17.78$ & $17.868 \pm 0.547$ \\
\hline $\mathrm{CD}$ at $5 \% \mathrm{P}$ & 1.35 & 11.47 & 2.729 \\
\hline
\end{tabular}

In terms of in vivo nitrogenase $\left(\mathrm{N}_{2}\right.$-ase) activity on root surface too, rather than individual action of inoculation of A. chroococcum or individual inputs of exogenous nitrogen, combined action was better and significant when input of exogenous nitrogen was at the level of 40 $\mathrm{kg} \mathrm{ha} \mathrm{ha}^{-1}\left(\mathrm{~N}_{1} \mathrm{~B}_{1}\right)$ or $60 \mathrm{~kg} \mathrm{ha}^{-1}\left(\mathrm{~N}_{2} \mathrm{~B}_{1}\right)$. When input of exogenous nitrogen was increased to $80 \mathrm{~kg} \mathrm{ha}^{-1}\left(\mathrm{~N}_{3} \mathrm{~B}_{1}\right)$, the nitrogenase activity was found even lesser than the treatment having no nitrogen and no bioinoculant
$\left(\mathrm{N}_{0} \mathrm{~B}_{0}\right)$. Highest nitrogenise activity was recorded in the treatment which was inoculated with A. chroococcum and integrated with $60 \mathrm{~kg} \mathrm{~N} \mathrm{ha}^{-1}\left(\mathrm{~N}_{2} \mathrm{~B}_{1}\right)$ followed by the treatment having inoculation with $A$. chroococcum and input of $40 \mathrm{~kg} \mathrm{~N}$ ha ${ }^{-1}\left(\mathrm{~N}_{1} \mathrm{~B}_{1}\right)$. The lowest nitrogenise activity was recorded in the treatment having input of 40 $\mathrm{kg} \mathrm{N}$ ha $^{-1}$ alone $\left(\mathrm{N}_{1} \mathrm{~B}_{0}\right)$, and even it was lesser than the treatment having no bioinoculant and no input of exogenous nitrogen $\left(\mathrm{N}_{0} \mathrm{~B}_{0}\right)$.

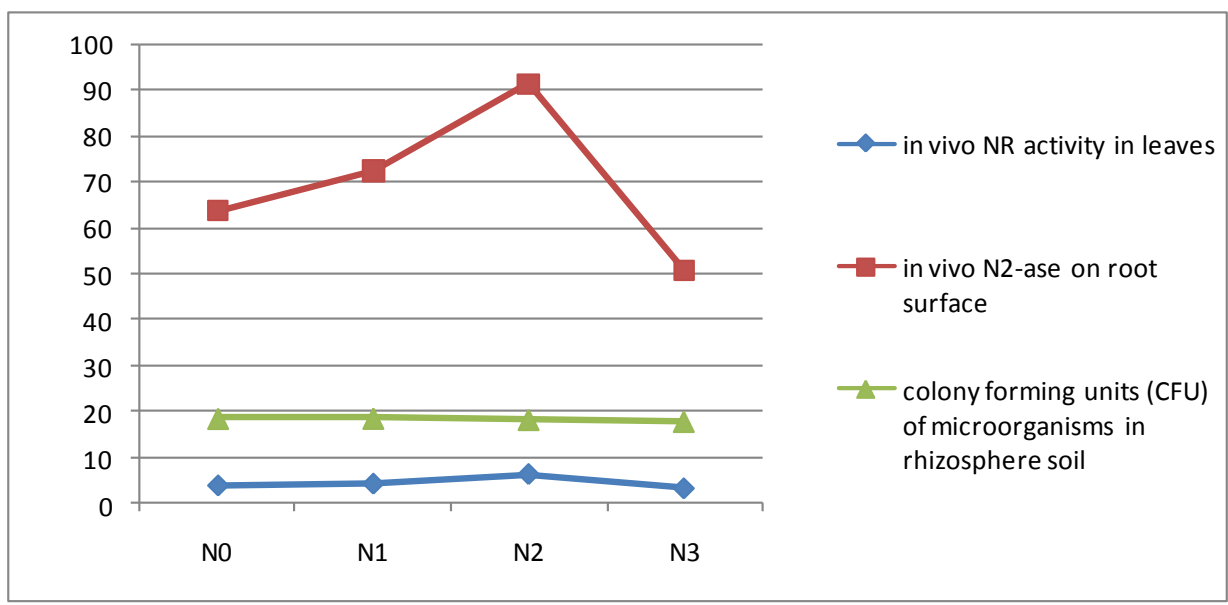

Fig. 1: Comparison of percentage of increase or decrease in the in vivo nitrate reductase (NR) activity in leaves, in vivo $\mathrm{N}_{2}$-ase activity on root surface microorganisms and colony forming units (CFU) of microorganisms in rhizosphere soil on inoculation with A. chroococcum in integration with different level of exogenous nitrogen. 
The percentage of increase or decrease in the in vivo nitrate reductase (NR) activity in leaves, in vivo $\mathrm{N}_{2}$-ase activity on root surface microorganisms and colony forming units (CFU) of microorganisms in rhizosphere soil on inoculation with $A$. chroococcum in integration with different level of exogenous nitrogen is shown in Fig. 1. Both the inoculation of A. chroococcum and input of exogenous nitrogen alone or in combination with urea nitrogen also resulted increase in the CFU of microorganisms in the rhizosphere soil, though differences among the treatments were not significant. In the treatments with input of exogenous nitrogen alone, CFU recorded highest in treatment having $40 \mathrm{~kg}$ $\mathrm{N}$ ha ${ }^{-1}\left(\mathrm{~N}_{1} \mathrm{~B}_{0}\right)$ and the $\mathrm{CFU}$ found decreased in the treatments with input of increased exogenous nitrogen (60 kg N ha ${ }^{-1}$ in $\mathrm{N}_{2} \mathrm{~B}_{0}$ ) and with further increase of nitrogen $\left(80 \mathrm{~kg} \mathrm{~N} \mathrm{ha}^{-1}\right)$ CFU decreased further $\left(\mathrm{N}_{3} \mathrm{~B}_{0}\right)$. In the treatments having combination of inoculation of A. chroococcum and exogenous nitrogen at different levels, similar trends were also recorded.

\section{Discussion}

Both the inoculation of A. chroococcum and supply of exogenous nitrogen alone or in combination resulted in increase in both in vivo nitrate reducatse (NR) activity in leaves and in vivo nitrogenase $\left(\mathrm{N}_{2}\right.$-ase) activity on root surface micro-organisms, which are indication of efficiency of nitrogen fixation. But, high level of nitrogen inputs retarded both the activities, which substantiate the postulation of Shrestha and Maskey (2005) that, synergistic effect of low $\mathrm{N}$ application and suppressive effect of high $\mathrm{N}$ application in $\mathrm{N}_{2}$-fixation in integration with diazotroph.

Shrestha and Maskey (2005) also mentioned that, in long ago it has been observed that, in the in vitro experiments when mineral nitrogen was present in the growth medium $\mathrm{N}$-fixation was retarded and he had doubt whether there will be same trend in in vivo. The present study of in vivo experiment showed the similar trends and substantiated the observation of other researchers including Sattar et al. (2008), who experimented in field condition.

The benefit of the integrated use of inorganic fertiliser with bioinoculants have been reported for many crops including rice (Das and Saha, 2003; Bashan et al., 2004; Wu et al., 2005; Rajaee et al., 2007; Shaheen et al, 2007; Fakir et al., 2008), which have also been substantiated by the present finding that, rather than individual action combined action of bioinoculation and exogenous nitrogen at low inputs is better.

Several researchers revealed that, inputs of high level mineral nitrogen retard the biological nitrogen fixation (Mc Auliffe, 1958; Boller and Heichel, 1983; Henson and Heichel, 1984), which is true on application of mineral nitrogen both in alone and in integration with bioinoculation in the present study. This is due to decrease of nitrogenase $\left(\mathrm{N}_{2}\right.$-ase $)$ activity as a result of inhibitory role of excess nitrogen (in the form of $\mathrm{NH}_{4}{ }^{+}$ or $\mathrm{NO}_{3}^{-}$ions) on nitrogenise enzyme, as reported by scientists including Srivastava and Mathur (1980) and Srivastava (1981).

In the present study, both in case of application of mineral nitrogen alone and in combination with A. chroococcum it has been found that, the nitrate reductase (NR) activity in leaves is high, in comparison to nitrogenise $\left(\mathrm{N}_{2}\right.$-ase) activity on root surface. This may be due to the result that, instead of $\mathrm{N}$-fixation, the plants took up preferably mineral $\mathrm{N}$ for its metabolism as observed earlier by Merbach (1995), which resulted in increased NR activity, though corresponding nitrogenase $\left(\mathrm{N}_{2}\right.$-ase) activity was less due to inhibitory role on enzyme responsible for nitrogenase activity.

Trends of changes in microorganisms population in rhizosphere soil expressed in terms of CFU due to input of mineral nitrogen and inoculation of A. chroococcum, both in alone or in combination indicated that, while in low input of mineral nitrogen $\left(40 \quad \mathrm{~kg} \mathrm{ha}^{-1}\right)$ microorganism population was high, which decreased on application of high level of mineral nitrogen $\left(60 \mathrm{~kg} \mathrm{ha}^{-1}\right.$ or $80 \mathrm{~kg} \mathrm{ha}^{-1}$ ), which may be due to elimination of diazotrophs as observed earlier by Kalininskaja (1988), who postulated that the application of high level of mineral nitrogen decreased the number of diazotrophs or eliminated them from the radical zone of plants. The present study indicated that, A. chroococcum has sensitivity to exogenous nitrogen and hence, it performs better in optimal input of mineral nitrogen, but its activity is retarded when level of exogenous nitrogen is high.

Similar trends of increase or decrease in different parameters viz., in vivo nitrate reductase (NR) activity in leaves, in vivo nitrogenise $\left(\mathrm{N}_{2}\right.$-ase) activity on root surface microorganisms and colony forming units (CFU) of microorganisms of soil indicates that, above optimal level input of exogenous nitrogen in soil reduced the 
number of free-living nitrogen fixing bacteria from rhizosphere soil and have played inhibitory role of enzyme responsible for nitrogenase activity on root and as a consequence availability of nitrogen to the plant was minimised to a great extent and resulted less nitrate reductase (NR) activity in leaves.

\section{Conflict of interest statement}

Authors declare that they have no conflict of interest.

\section{References}

Anonymous, 2006. Agriculture, forestry and other land use. IPCC guidelines for national greenhouse gas inventories, Vol.4. Intergovernmental Panel on Climate Change (IPCC), Geneva, Switzerland.

Bashan, Y., Holguin, G., De-Beshan, L.E., 2004. Azospirillum - plant relationship: Physiological, molecular, agriculture and environmental advances (1997-2003). Can. J. Microbiol. 50, 521-577.

Begum Jhamida, Z.N., Mandal, R., Islam, S., 2011. Effect of cyanobacterial biofertilizer on the growth and yield components of two HYV of rice. J. Algal Biomass. 2(1), 1-9.

Boller, B.C., Heichel, G.H., 1983. Photosynthate partitioning in relation to $\mathrm{N}_{2}$ fixation capacity of alfalfa. Crop Sci. 23, 655-659.

Choudhury, A.T.M.A., Kennedy, I.R., 2005. Nitrogen fertilizer losses from rice soils and control of environmental pollution problems. Soil Sci. Plant Anal. 36, 1625-1639.

Chowdhury, A.T.M.A., Khanif, Y.M., 2001. Evaluation of the effects of nitrogen and magnesium fertilizers on rice yield and fertilizer nitrogen efficiency using ${ }^{15} \mathrm{~N}$ tracer technique. J. Plant Nutr. 24, 855-871.

Chowdhury, A.T.M.A., Khanif, Y.M., 2004. Effects of nitrogen and copper fertilization on rice yield and fertilizer nitrogen efficiency: $A{ }^{15} \mathrm{~N}$ tracer study. Pak. J. Scient. Indust. Res. 47: 50-55.

Conway, E.J., 1957. Modern methods of plant analysis. In: Micro-diffusion Analysis and Volumetric Error (Eds.: Linskens, H.F, Sanwal, B.D., Tracey, M.V). $4^{\text {th }}$ Edn. Springer-Verlag, Berlin.

Das, A.C., Saha, D., 2003. Influence of diazotrophic inoculations on nitrogen nutrition of rice. Aust. J. Soil Res. 41(8), 1543-1554.

De Datta, S.K., 1978. Fertilizer management for efficient use in wetland rice soils. In: Soils and Rice (Ed.: Ponnamperuma, F.N.). IRRI, Philippines. pp.671-701.
Fakir, M.A.I., Hassan, S.M.R., Sattar, M.A., 2008. Growth and yield of rice as influenced by Azotobacter and Azospirillum inoculation in presence and absence of urea-N. J. Bangladesh Soc. Agric. Sci. Tech. 4, 247-250.

Falkowski, M., Kukulka, I., Kozlowski, S., 1990. Wlasciwosci chemiczne roslin lakowych. Wyd. Poznan: AR ss. 111.

Garbet, S., Ryan, J., Wood, M., 1998. Nitrogen and water effects on wheat yield in a Mediterraneantype climate. II. Fertiliser-use efficiency with labeled nitrogen. Field Crop Res. 58, 213-221.

Hageman, R.H., Hucklesby, D.P., 1971. Nitrate reductase from higher plants. In: Methods in Enzymology (Eds.: San Pietro, A.). Academic Press, London. 23A, 491-503.

Halvorson, A.D., Follett, R.F., Bartolo, M.E., Schweissing, F.C., 2002. Nitrogen fertilizer use efficiency of furrow-irrigated onion and corn. Agron. J. 94, 442-449.

Henson, R.A., Heichal, G.H., 1984. Dinitrogen fixation of soybean and alfalfa: Comparison of the isotope dilution and difference methods. Field Crop Res. 9, 333-346.

Kalininskaja, T. A., 1988. The influence of different forms of combined nitrogen on nitrogen-fixing activity of Azospirillum in the rhizosphere of rice plants. Dev. Soil Sci. 18, 283.

Mc-Auliffe, C., Chamblee, D.S., Uribe-Arango, H., Woodhouse, W., 1958. Influence of inorganic nitrogen on nitrogen fixation by legumes as revealed by ${ }^{15}$ N. Agron. J. 50, 334-337.

Merbach, W., 1995. Relationship between combined N and symbiotic $\mathrm{N}_{2}$ fixation of legumes. In: $10^{\text {th }}$ Int. Cong. on Nitrogen Fixation (Abstract Volume), 28 May-3 June, 1995. Saint Peterburg, Russia.

Rajaee, S., Alikhani, H.A., Raiesi, F., 2007. Effect of plant growth promoting potentials of Azotobacter chroococcum native strains on growth, yield and uptake of nutrients in wheat. J. Sci. Technol. Agric. Nature. Resour. II(41b), 297-301.

Refsgaar, K., Halberg, N., Kristensen, E.S., 1998. Energy utilisation in crop and diary production in organic and conventional livestock production systems. Agric. Syst. 57, 48-53.

Roger, P.A., Kulasooriy, S.A., 1980. Blue-Green Algae and Rice. IRRI, Phillippines. 112p.

Sattar, M.A., Rahman, M.F., Das, D.K., Choudhury, T.M.A.A., 2008. Prospects of using Azotobacter, Azospirillum and Cyanobacteria as supplements of urea nitrogen for rice production in Bangladesh. In: 
Proceedings of ACIR, 130, 59-66.

Shaheen, A.M., Fatma, A. R., Omina, M. S., Ghoname, A.A., 2007. The Integrated use of bioinoculants and chemical nitrogen fertilizer on growth, yield and nutritive value of two Okra (Abelmoschus esculentus L.) cultivars. Aust. J. Basic Appl. Sci. 1(3), 307-312.

Shrestha, R. K., Maskey, S. L., 2005. Associative Nitrogen fixation in Lowland rice. Nepal Agric. Res. J. 6, 112-121.

Srivastava, R.C., Mathur, S.N., 1980. Nodulation and nitrate reductase activity in nodules and leaves of black-gram (Vigna mungo) as affected by varying day-lengths. Ind. J. Exp. Biol. 18(3), 300-302.

Srivastava, R.C., 1981. Effects of some nitrogenous and non-nitrogenous fertilizers on nitrogen metabolism of Phaseolus mungo L. Ph.D. Thesis, University of Gorokhpur, India.
Srivastava, R.C., Mukherjee, D., Mathur, S.N., 1980. A freez / thaw technique for estimation of nitrogenise activity in detached nodules of Vigna mungo. Ann. Appl. Biol. 96, 235-240.

Swedrzynska, D., 2000. Effect of inoculation with Azospirillum brasilense on development and yield of winter wheat and oat under different cultivation conditions. Polish J. Environ. Stud. 9(5), 423-428.

Vincent, J.M., 1970. A Manual for the Practical Study of Root-nodule Bacteria. IBP Hand Book No. 15. International Biological Programme (IBP), 7, Marylebone Road, London, Blackwell Scientific Publication, Oxford.

Wu, S.C., Cao, Z.H., Li, Z.G., Cheung, K.C., Wong, M.H., 2005. Effects of biofertiliser containing $\mathrm{N}$-fixer, $\mathrm{P}$ and $\mathrm{K}$ solubilizers and AM fungi on maize growth: A green-house trial. Geoderma. 125, 155-166.

\section{How to cite this article:}

Roy, M., Saha, S., Das, J., 2017. Sensitivity of Azotobacter chroococcum to exogenous nitrogen in rice cultivation in terms of nitrate reductase activity in leaves and nitrogenase activity on the root surface of the inoculated rice cultivar and its effect on microorganism population in rhizosphere soil. Int. J. Curr. Res. Biosci. Plant Biol. 4(2), 54-59. doi: http://dx.doi.org/10.20546/ijcrbp.2017.402.007 